\title{
(Neurogenic) Claudication
}

\author{
J.M.S. Pearce \\ Emeritus Consultant Neurologist, Department of Neurology, Hull Royal Infirmary, Hull, UK
}

Why do we use the term claudication for pain in the legs precipitated by exercise and relieved by rest? The word claudicate comes from the Latin claudicare, from claud-us to be lame, or to limp. It commonly refers to ischaemic muscular pains in the leg(s). Neurologists are involved in neurogenic claudication in which exercise precipitates radicular symptoms associated with spinal canal stenosis. Pain and paraesthesiae are worse when standing erect and walking downhill and relieved by lying supine, and lumbar flexion. Claudication is an ancient word, first noted in English literature in 1555 - the action of limping or halting. It became widely used in fashionable circles, so that the Tatler (No. 80. 37) of 1709 carried a statement 'I have contracted a very honest and undissembled Claudication in my Left Foot.'

But why and how did the Romans choose the word? Claudius (10 BC to $54 \mathrm{AD}$ ) was the most erudite of Roman emperors, ruling between 41 and $54 \mathrm{AD}$. The younger son of Nero Claudius, his full name was Tiberius Claudius Drusus Nero Germanicus. Probably from birth, he suffered from a kind of paralysis and was at first an object of ridicule, considered unfit for a public career. He limped, he drooled, he stuttered and was constantly ill. His family treated him with disdain, mistaking these physical debilities as signs of mental illness and concealed him from the public eye as an embarrassment. In his autobiography, Claudius wrote:

' $\{\mathrm{I}\}$ known to my friends and relatives and associates as "Claudius the Idiot", or "That Claudius", or "Claudius the Stammerer", or "Clau-Clau Claudius" or as "Poor Uncle Claudius", ...'

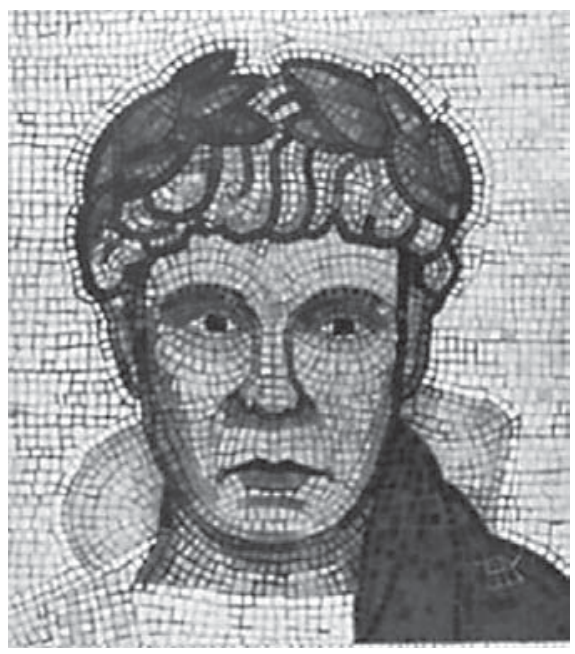

Fig. 1. 'I Claudius'.

Claudius probably suffered from the athetoid or dystonic variant of cerebral palsy $[1,2]$. In addition to a marked limp, he had abnormal movements of the head and hands [3], dysarthria, hypertrophy of neck muscles, unseemly laughter and anger. Improvement when 'declaiming' in public orations is quite consistent and reminds us of the disappearance of organic stammering when the patient starts to sing or shout.

He survived the political purges under his uncle Tiberius, and his nephew Caligula. When Caligula was assassinated in $41 \mathrm{AD}$, Claudius also expected to be murdered. Instead, the Praetorian Guard proclaimed him

\section{KARGER}

Fax +41613061234 E-Mailkarger@karger.ch www.karger.com
(C) 2005 S. Karger AG, Basel 0014-3022/05/0542-0118\$22.00/0

Accessible online at:

www.karger.com/ene
J.M.S. Pearce

304 Beverley Road

Anlaby, East Yorks HU10 7BG (UK) 
emperor of Rome. Claudius was a shrewd administrator; he pursued the policies of extending Roman citizenship and founding Roman cities in the provinces. He incorporated Britain, Mauretania, and Thrace into the Roman Empire. Despite his limp, he married three times. But, in $48 \mathrm{AD}$, his third wife, Messalina, was executed on the charge of conspiracy, and Claudius married his niece Agrippina II. He adopted her son Nero, thus paving the way to the throne for him and practically excluding from succession his own son, Britannicus. It is believed that Claudius was fatally poisoned by Agrippina.

$\mathrm{He}$ is the subject of two acclaimed biographical novels by Robert Graves, I, Claudius (1934; fig. 1) and Claudius the God (1934).
1 Pearce JMS: The emperor with the shaking head: Claudius' movement disorder; in Pearce JMS: Fragments of Neurological History. London, Imperial College Press, 2003, pp 588591.

2 Mottershead J: Claudius' physical appearance and health; in Suetonius: Claudius. Bristol, Bristol Classical Press, 1986, pp 145-148.

3 Rice E: The emperor with the shaking head: Claudius' movement disorder J R Soc Med 2000;93:198-202. 